\title{
Pickpockets, Pilot Boys and Prostitutes: The Construction of Juvenile Delinquency in the Gold Coast [Colonial Ghana], c. 1929-57
}

Abstract:

In twentieth-century Gold Coast youth offending became a metonymy for wider concerns about the impact of urbanization and colonial modernity. Urbanization, migration, unemployment, poverty, the disintegration of family and tribal structures, and Western culture were all blamed for the emergence of delinquency. This article analyzes changing constructions and treatment of delinquency from c.1929-57, drawing on contemporary sociological research, popular culture and metropolitan debates, as well as archival material from Prisons, Welfare and Probation departments in Accra. Whilst in other parts of West Africa, fears about delinquency focused on gangs and violence, the main categories of delinquency in the Gold Coast were: theft; 'immoral' offences; intelligent offenders and proto-criminals; and 'care and protection' cases. Rehabilitation was marked by a constant tension between punishment, reform, and the construction of economically-productive colonial citizens. Juvenile delinquency formed a significant and symbolic part of the disciplinary techniques, discourses and institutions of the late-colonial state.

Keywords: Juvenile delinquency, Ghana, Gold Coast, colonialism, crime, welfare, childhood.

Character and space count: 75,439. Words 11, 172 inclusive. 33 pages (double-spaced text). 


\title{
Pickpockets, Pilot Boys and Prostitutes: The Construction of Juvenile Delinquency in the Gold Coast [Colonial Ghana], c. 1929-57
}

\author{
"I know the general conduct of my son to be a bad one. He is a truant, \\ vagabond, and does not stay at home. He always goes about in bad \\ company, and he leads other boys into wrong-doing. Both the father \\ and I have tried very much to check him without success. In fact the \\ boy is uncontrollable...I will be pleased if he is sent to the Boy's \\ Industrial Home of the Government". 1
}

- Ama Badua to District

Magistrate, Sekondi, 1943.

Ama Badua, mother to a young boy who had been repeatedly convicted of stealing, was but one of thousands of parents whose children's deviant and 'delinquent' actions brought them to the attention of the colonial state's apparatus of social control in the Gold Coast. As a growing body of historical studies of African juvenile delinquency have suggested, in the late-colonial era youth offending became a metonymy for wider concerns about the impact of urbanization and colonial modernity: "destitution, prostitution, overcrowding, disease, rent exploitation and a general preoccupation with the acquisition of wealth" were held to foment delinquent and deviant behaviour in both popular and official discourses. ${ }^{2}$ Categories of "juvenile" and "delinquent" became almost synonymous due to the ambivalent position of youth in colonial society. As Richard Waller has argued, colonialism relied on co-opting youth for its future, but it also granted youths access to educational resources and social spaces 
which allowed them to challenge both colonial authority and the generational and gendered hierarchies which underpinned African societies. ${ }^{3}$ Increased access to globalized youth cultures and commodities gave children in the Gold Coast a glimpse of the world beyond their immediate horizons and spurred many to actively seek such experiences - of movies, bicycles, or Western clothes - which could often be most easily achieved through delinquent activities. The questions for the historian however are not simply whether juvenile delinquency was truly evidence of "detribalisation" the perceived deleterious impact of Western cultures and urbanisation on African communities and moralities -, but why and how it became understood as such by colonial officials and some Gold Coast Africans? ${ }^{4}$ Can delinquency be better analysed as a marker of the development of a colonial intelligence-gathering disciplinary apparatus, or as a marker of social tensions within African urban communities? What can studying delinquency tell the historian about notions of 'childhood' in colonial Ghana? Juvenile delinquency is read here as part of a larger history of the disciplinary techniques, discourses and institutions of the colonial state in Africa: part of the failures and limited success of such projects, and the "stutters" between reforming ideals and the reality of coercion and criminalization. ${ }^{5}$

The treatment of juvenile delinquency was part of broader colonial efforts to "modernize" childhood and harness the potential of African children as future colonial subjects. The first systems of treatment for juvenile criminality in Africa emerged in the late nineteenth-century, with reformatories for "poor whites" and labouring blacks in South Africa and penitentiary schools in French West Africa, before spreading to British Africa in the early twentieth century. ${ }^{6}$ Across British colonies the management of juvenile delinquency was influenced by metropolitan trends, with nineteenth-century fears regarding the deleterious impact of urbanization 
on the working class and the criminalization of delinquency giving way in the interwar years to a more rehabilitative system of treating juveniles, marked by the emergence of the Borstal system. ${ }^{7}$ With the appointment of a Penal Sub-Committee on Juvenile Delinquency by the Colonial Office in 1941, this reformative programme was earmarked for official adoption across British colonies. ${ }^{8}$ The implementation of juvenile reform however proved problematic due to limited resources, and the "need to preserve the racial difference between civilized and the savage severely complicated the ideological location of the reformed criminal". 9 The juvenile justice system was therefore shaped by a persistent tension between physical discipline, education, socialization, and labour as the key to creating obedient, productive, future colonial subjects.

Whilst legal and institutional structures targeting youth offenders emerged in the inter-war period, it was the Second World War that transformed juvenile delinquency into a recognized social problem across Africa. ${ }^{10}$ Wartime development and increased road transportation brought marginal or aspiring youths to the cities where they were drawn into, or continued, delinquent practices in an environment deemed "detribalized" and potentially immoral by both African and colonial commentators. ${ }^{11}$ In the Gold Coast, new forms, categories, and levels of delinquency emerged as part of a generalized youth crisis, from "pilot boys" to young prostitutes and "semi-educated" proto-criminals, but also "care and protection" cases aimed at rescuing vulnerable youths before they transitioned from marginality to delinquency. The identification and treatment of this delinquency was part of the wider development of colonial social welfare in the post-war period, as Britain sought to justify and re-assert its continued control over its empire. ${ }^{12}$ The mandates and the personal files of delinquents sent to government institutions from 1930-37 and 1940- 
47 extant in the National Archives of Ghana, Accra, form the first body of evidence upon which this article is based. ${ }^{13}$ Attitudes towards delinquency were also reframed as the Gold Coast government was 'Africanized' in the run-up to independence, with local staff replacing colonial officials. Another key archival resource therefore are the investigations by Ghanaian probation officers into the circumstances surrounding individual delinquents' actions, archived with Juvenile Court records from 1946-57. The use of personal files and probation reports allows a new, more individuated analysis of delinquency to be undertaken, highlighting colonial responses to varying types of juvenile offenders and their characters. Probation records and personal files must be treated with due caution: they provide constrained narratives shaped by bureaucratic forms, being justifications for action by colonial officials and secondhand retellings of children's attempts to explain their actions in the face of punishment. Nevertheless, these records grant the historian useful insight into the domestic tensions of African families and children's lives in the late colonial period. The data from these archival sources is read here against contemporary sociological and criminological studies and commentaries on youth behaviour and child-rearing in African newspapers to elucidate changing conceptions of delinquency in the Gold Coast. This article looks at theories behind the emergence of 'juvenile delinquency' in the early twentieth-century, before exploring the various categories of delinquency and what they reveal about Gold Coast childhoods, families and the weaknesses of colonial rule. Finally it will look at the disciplinary techniques and infrastructures which aimed to combat delinquency, and the tensions between 'punishment' and 'reform' which shaped these coercive networks. ${ }^{14}$ 
Childhood is not a universal category but rather an historical and cultural construct, and in the Gold Coast it proved to be a site of contestation between, and within, African communities and colonial states. ${ }^{15}$ In the nineteenth and twentieth-centuries middle-class Western notions of childhood were exported across Africa and the colonized world. ${ }^{16}$ Historically, as today, Western constructions of childhood served as a global disciplinary tool and moralizing practice, blaming 'bad' or 'vulnerable' children on the failings of African social structures and cultures. ${ }^{17}$ In twentiethcentury Gold Coast welfare officials increasingly adopted these universal models of childhood, seeing delinquents as "children" rather than just young "Africans". These models read children as innocent, nonsexual beings who should be protected from labour and too rapid a transition into adulthood: a status which bore little resemblance to the lived realities of many African juveniles, particularly those from poorer families. ${ }^{18}$ Colonial constructions of childhood contrasted sharply with African understandings of that life stage. In most precolonial and colonial African communities, childhood refers more to a position in social hierarchy than biological age: children were individuals in a dependent position within a community, who could not yet undertake the acts of marriage, reproduction, and establishing their own households that would grant them 'adult status'. ${ }^{19}$ Rather than a life stage in and of itself, childhood was primarily conceived of as period of socialization and progression towards adulthood, where correct behaviour was learned. Whilst Western societies see children as protected consumers, African children are generally held as capable of contributing to the family and community economy. Lord argues that in the Gold Coast children were viewed as both "chattels and changelings", who were a store of wealth that could be utilised for the good of the community and who acquired their 
full humanity and social rights only gradually as they matured..$^{20}$ This is not to say that children were not also loved, cherished and protected, but simply to highlight the different expectations of and about children as social actors. 'Childhood' is a problematic category for historical analysis as it contains multiple sub-categories: babies, infants, pubescents, teenagers, boys and girls, not all of which have clear analogues across Gold Coast ethnic cultures. 'Youth' similarly is a slippery term, a political label more than a biological category generally connoting an incomplete transition towards adulthood which is applied predominantly applied to males between the ages of fourteen to thirty-five, as with the Gold Coast's 'youngmen'. ${ }^{21}$ The majority of juvenile delinquents were, biologically at least, teenagers, but for ease of analysis the label 'juvenile' will be retained throughout this article, although a breakdown of ages and offenders own perceptions of their age-group identity will be given where possible.

Children had undoubtedly misbehaved and resisted familial and generational authority in the Gold Coast throughout the region's history, as suggested in folklore, morality tales, and traditions of domestic corporal discipline. ${ }^{22}$ But the concept of "juvenile delinquency" and the question of how best to combat it first emerges in the colonial archive around 1906-1911. ${ }^{23}$ With thirty to seventy juveniles being imprisoned alongside adults each year and many more being whipped, early official discussions focused on necessity of segregating of youths within prisons to avoid the "grave danger of [youths] being contaminated by contact with older and more experienced criminals". ${ }^{24}$ African elites were also concerned about badly-behaved youth, with the paramount chiefs of the Eastern Province arguing in 1918 for a separate reformatory institution to be built. Spurred to action, in 1921 Governor Guggisberg requested a scheme for juvenile detention "based on the English 
model". ${ }^{25}$ However, despite reports of police magistrates struggling to cope with increasing numbers of juvenile offenders, it was not until 1929 that the capital, political will, and personnel were all available to open the first establishment in the Gold Coast dedicated to the care and reformation of delinquent youths, the Boy's School at Ada, which was placed under Salvation Army supervision following the model established in Lagos. ${ }^{26}$ Further action was delayed by financial constraints generated by the Great Depression.

Alongside the establishment of institutional mechanisms to combat delinquency came its construction as a legal category defined by biological age; a category which cut across existing local cultural boundaries of "childhood" and processes of social maturation. In the Gold Coast, the colonial definition of a "juvenile" legally had an upper age limit of sixteen years, with those sixteen to twenty years of age categorized as young offenders: however, these categories were often conflated in practice. ${ }^{27}$ Children under the age of seven were regarded as doli incapax, but the criminal responsibility of those between seven and twelve years was to be judged on an individual basis. ${ }^{28}$ The Child (Care and Reformation) Ordinance of 1928 specifically applied only to those youths adjudged "not over fifteen", who could be held they turned eighteen. ${ }^{29}$ These measures effectively legislated delinquency into existence, and the numbers of juveniles brought into the colonial legal system increased rapidly, jumping from around two to three hundred per year in 1920-30s , to five to eight hundred in the late $1940 \mathrm{~s}$, and to over one thousand in the mid-1950s. ${ }^{30}$ Personal files of delinquents extant in the archives and official reports suggest that the peak age for delinquents was around fourteen years old, with the thirteen to sixteen age group considered most "lawless". However, there is a level of inexactitude in this data due to the lack of birth certificates for most offenders, and police and medical 
officers reportedly skewed offenders' ages to ensure or avoid particular categories of punishment that were age-defined. ${ }^{31}$

Explaining Delinquency: "He is my own son but I can say he is a bad boy he respects no body and has become a thief', 32

In 1945 a Colonial Social Science Research Fellow, Geoffrey Tooth, was commissioned to perform the first expert investigation into delinquency in the Gold Coast, focusing on incidences of psychosis and neurosis among convicted delinquents. Early studies from elsewhere in West Africa apparently suggested that many identified delinquents "were psychopathic, schizophrenic, paranoiacs and hysterics and that those reactions might be associated with the breaking up of homes and loss of parents". ${ }^{33}$ However, Tooth quickly determined that juvenile delinquency in the Gold Coast was not linked to mental instability, and began instead a general survey on the state of delinquency in the colony. Tooth identified a number of competing explanations for the apparent upsurge in delinquents: "Economists blame the adoption of the Western cash economy, with the consequent drift towards the towns, Educationalists, especially Africans, are inclined to back compulsory schooling as the solution. Sociologists, and to some extent missionaries, see in juvenile lawlessness the fruits of the disintegration of the old social and religious structures before the 'impact of Western civilisation'". ${ }^{34}$ More widely across British Africa, migrancy, housing shortages, unemployment, poverty and overcrowding in urban areas were all blamed for delinquency. ${ }^{35}$ 
Environmental theories which focused on the impact of detribalization, poverty and urbanization had dominated inter-war discussions of delinquency. ${ }^{36}$ As the district magistrate of Accra commented in early 1940 upon an eleven year old Ewe boy convicted of possession of stolen cigarettes, "I am of the opinion that in the atmosphere of Accra he will go from bad to worse, and that only the healthier environment of Kintampo [Boy's School] will change him from being a criminal to a useful citizen". ${ }^{37}$ By the 1940s however greatest blame was placed on a lack of parental control over children in urban environments, reflecting concerns about the break-up of 'the family' in urban spaces: what modern criminology would term social disorganization theory, under which the breakdown of social controls in a locality lead to delinquent outbursts. ${ }^{38}$ Sociologist (and future Prime Minister) Kofi Abrefa Busia argued in his social study of Sekondi-Takoradi that "delinquency was primarily due to the failure of home life": the repudiation of parental responsibility for children's behaviour, the breakdown of family structures, and fostering to uncaring guardians. ${ }^{39}$ Investigations found no significant association between ethnicity, religion or family size and delinquent behaviour, but noted that around half of delinquents were from "broken homes", with one parent dead or deserted. ${ }^{40}$ Female economic activity in street trading was blamed for "long periods when [the child] is left alone or without sufficient supervision". ${ }^{41}$ Such assessments apparently held weight among literate, urban Gold Coast society, with the Gold Coast Times railing against "many mothers of both classes of the educated and uneducated [who] are unable to exercise tolerance and evince the spirit of affection towards their own children. They are in the shameful habit of continually slapping, whipping, shaking and striking children often on the slightest provocation". ${ }^{42}$ Rural parents were held to devote greater care to rearing and socializing their children than those in urban environments. ${ }^{43}$ The 
Department of Social Welfare and Community Development continued to argue throughout the 1950s that a "lack of parental support" was the primary determinant of delinquency. ${ }^{44}$ In January 1955, probation officer J. B. Amoaku addressed a rally of the Gold Coast Women's Federation in Accra, arguing that the main causes of delinquency were "broken homes and loose marriages", and calling for women to press for reform of Native Customary marriages "to prevent men abandoning their wives and children". ${ }^{45}$

As the welfarization of delinquency increased from the late 1940s onwards there was a growing bureaucratic concern with - and capacity to investigate - the domestic conditions which engendered delinquent behaviour, with pre-trial investigations made by probation officers into the family background and living conditions of accused young offenders. A typical case was that of a young boy convicted of stealing goods to the value of 16/- from a dwelling house in Accra in 1946. His case history revealed that the boy had appeared in the same court only a fortnight before on a charge of larceny and had four previous convictions. He stated that his father was a Sierra Leonean contractor at Tafo, and his mother was from Cape Coast. When the boy was nine months old his mother had left home after stealing from the father, and the boy was placed in the care of a Child Welfare Clinic until he was two. After that, during the dislocation of the war years, he had been shuttled back and forth between being under the charge of his father, his father's friends, or sleeping rough and stealing to survive. ${ }^{46}$ Judging from such case files, it was a disrupted upbringing marked by frequent changes in habitation and guardianship that was felt most likely to cause delinquency. The variety of cultural practices and social networks regarding the raising of children in the Gold Coast however made it difficult for welfare officers to generalise about the ideal domestic environment. Polygyny was 
legal and widespread and multi-nodal households were also common, with children moving between living with mothers and fathers. ${ }^{47}$ Such arrangements, together with the common practice of fostering children with relatives, were not automatically viewed as a broken home by experienced officials, but as a modernized adaptation of the traditional practice of collective rearing of children by the kin group. ${ }^{48}$

Locating the Colonial Delinquent: Urbanization, War and the Categories of Delinquency

Although young offenders had been a recognized category of criminal in the Gold Coast since the turn of the century, it was the Second World War that was held to have created the wider social phenomenon of delinquency; not just through the "general restlessness and economic hardships" engendered, but also through social dislocation and the stationing of foreign troops on the coast bringing direct contact with enticing new forms of modernity. ${ }^{49}$ Soldiers created rising demand for prostitution, with areas like Kotokoli in Accra becoming major arenas of the sex trade. ${ }^{50}$ During the war years, young boys in Sekondi-Tokoradi began acting as "pilot boys", or pimps, for foreign servicemen, haunting dance halls and bars and affecting introductions to prostitutes. ${ }^{51}$ These pilot boys became the most notorious delinquents in the Gold Coast. For their services these boys could earn the substantial sum of 18/per night; "the number of Europeans was great, drink was cheap and the African night is long", with many boys also operating as thieves who robbed drunken sailors at the end of the evening. ${ }^{52}$ Pilot boys were regarded not simply as delinquent but as dissolute sites of potential social infection. In 1943, two such pilot boys were charged with indecent assault before the district magistrate of Sekondi who noted that "the two 
accused in assaulting this woman showed a sophisticated sensuality that might cause slight surprise if one was not informed that they are two of the most flourishing pimps in Takoradi". 53

Primarily however delinquency meant theft, with over eighty per cent of the 2480 convictions from $1937-45$ being for property-related offences. ${ }^{54}$ A committee appointed by Governor Burns to inquire into juvenile delinquents in 1942 noted that "[t]he majority were linked up with small groups of boys from three to five in number, the members of each groups stealing and receiving in turn", but others involved "organized gangs operating on 'the Fagin principle'... [with boys] employed by unscrupulous adults". ${ }^{55}$ Stealing tended to be instrumental, usually involving small sums of food or goods up to the value of $£ 5$, whilst survival-orientated theft was mostly associated with runaways and unemployed migrants from the Northern Territories. Market sellers were common targets, and pickpockets found easy pickings among large crowds, but a significant number of offences involved stealing from family members in domestic residences. ${ }^{56} \mathrm{~A}$ number of delinquents appear to have had more determined, acquisitive objectives behind their thefts. Several of the boys brought before colonial courts were regarded as "seasoned and successful" thieves, with up to nine previous convictions. ${ }^{57}$ Some appear to have acted under adult influence, such as the fifteen-year old Fanti boy convicted of stealing $£ 3$ from the Harvest Thanksgiving box at the English Church Mission in Sekondi in 1931 who stated that he did it "to get native medicine from [adult co-accused] who promised it would boost his brain power", allowing him to gain an education and move to America. ${ }^{58}$ Others apparently acted independently, like the ambitious steward boy who was convicted of stealing $£ 135$ from a mine office in Bibiani in $1940 .{ }^{59}$ One Twi boy who confessed to housebreaking claimed that he stole because his grandmother 
had refused to buy him a bicycle. ${ }^{60}$ The growing impact of Western culture and global commodities was blamed by many officials for engendering criminal desires. As the Assistant Commissioner for Probation and Juvenile Delinquency, J. C. Hamilton, noted in 1953 "[t]ogether with poverty and slums comes something new - speed; speed of life in general, motor cars, bicycles and aeroplanes; speed engendered by the knowledge of life outside which education brings. Many feel the disparities and a desire of the comforts and material benefits of a relatively new civilization, which are in front of any child as he walks down the main street of any town" ${ }^{61}$ However, rather than simply analysing such delinquent behaviour as an uncritical desire for global communities and 'Western' cultural forms, it must be noted that children in the Gold Coast were significant economic actors, contributing labour to local economies and social units, with established historical patterns of childhood accumulation of individual property. ${ }^{62}$ As such, many thefts were likely attempts to accumulate goods which could be transformed into the financial or social capital necessary for survival and the eventual attainment of "economic adulthood". ${ }^{63}$ Delinquency here becomes a more of a rational choice for individual survival or advancement. ${ }^{64}$

By the 1950s male delinquency was becoming increasingly equated with youth subcultures, with urban gangs such as the "Canoe Boys" or "Kaaya Kaaya Boys" who roamed city centres and adjacent villages, spending "their time gambling when not engaged in odd jobs or stealing". ${ }^{65}$ Gangs actively recruited youths from neighbouring villages, luring in "innocent or credulous boys...by telling them alluring stories of their lucrative and adventurous life". ${ }^{66}$ These gangs were predatory, criminal actors, but they also offered protection, honour and alternative family structures to members. ${ }^{67}$ There was less concern with "vicious hooliganism" in the Gold Coast than in other West African cities like Lagos however: convictions for 
violent offences were relatively rare, and the accused tended to be older, rural boys with a history of aggression. ${ }^{68}$ With fighting regarded as normative behaviour and a marker of social status for young males, it was apparently tolerated by the police or dealt with extra-judicially within communities so long as it did not result in serious injury. Other offences which brought juveniles under the colonial gaze included fraud, criminal harm, assault, manslaughter and indecent assault. ${ }^{69}$

As colonial welfarism and the 'Africanization' of the colonial state progressed in the run up to independence, attempts to manage delinquency became increasingly pre-emptive and interventionist. ${ }^{70}$ In the 1950 s there was a marked rise in juveniles being accused of being "exposed to moral and physical danger", loitering or vagrancy. ${ }^{71}$ Children of known criminals or prostitutes were brought to court on "care and protection" charges. ${ }^{72}$ There was an expansion of conceptions of delinquency to encompass girls, with female youth crime primarily conceived of in terms of uncontrolled and deviant sexuality. ${ }^{73}$ In the Gold Coast female delinquency had previously been uncommon and mainly consisted of "petty misdemeanours" compared to the strong official concern about female delinquency and street hawking in Nigeria. ${ }^{74}$ Concerns about unfeminine and disrespectful behaviours among young girls however began to emerge in popular discourse during the war. In 1939 "Uncle Charlie" of the Gold Coast Times noted that during Christmas week "it was sad and shameful to see young girls drunk and reeling in the streets singing all sorts of unwholesome songs". ${ }^{75}$ With the growth of regional prostitution networks trafficking young girls across West Africa and a post-war legislative assault on female delinquency in Lagos, officials in the Gold Coast turned their attention to girls in marginal urban spaces. ${ }^{76}$ In the 1950 s rising numbers of cases apparently linked to prostitution and soliciting were brought before Juvenile Courts as officials felt "girls 
increasingly came to view prostitution as easier than trading or domestic service". ${ }^{77}$ Official reports noted that "some [girls] have defied the authority of family and friends and taken to roaming the streets at night in the company of anyone they can pick up and are heading for trouble". ${ }^{78}$ Although the numbers of such girls remained relatively small, the problem was taken as indicative of a wider problem of women "abusing the privilege of their new found freedom in towns". ${ }^{79}$

Reflecting this concern, the majority of girls brought before Juvenile Courts were there on "care and protection" charges with the intention of preventatively rescuing them from moral contagion. ${ }^{80}$ One such case was that of a Nigerian-born girl brought before the Juvenile Court in Accra in August 1952. Although the court noted she was well-cared for by her aunt, who had brought her to Accra after finding the girl living in "unwholesome circumstances" in Port Harcourt with her mother, she dropped out of school as "the beach and cinema room appealed to her better". According to her grandmother, the girl became disrespectful and used foul language, got into fights, and would collect food stuff from neighbours to sell before keeping the money. The girl was “"influenced by a group of young girls her age who are all birds of the same feather and have no parental control. It is at the water tap that they plan their movements". ${ }^{81}$ By 1954 the Accra court had become concerned about aggressive and "depraved" behaviour among female delinquents with the emergence of gangs of "Street Girls" in the city. ${ }^{82}$

It is notable that the majority of juvenile offences were committed in urban spaces: Accra (particularly Jamestown and Nima), Kumasi, Sekondi, Cape Coast and Koforidua. Delinquency was almost exclusively conceptualized as an urban phenomenon, although as the peno-legal structures developed to identify and combat delinquency were situated in urban locales this was something of a self-perpetuating 
image. Urban areas did certainly provide new spaces for self-expression and rebelliousness. ${ }^{83}$ Many youths were identified as "problem children" after frequenting adult environments like bars and Victoriaborg's racecourse, or known liminal spaces like cinemas. ${ }^{84}$ Cinemas in particular were identified as places of "dubious virtue", with parents reported to "feel strongly that it is the cinema that is undoing their boy". ${ }^{85}$ A 1953 report on cinemas in Accra and Kumasi concluded that the chief danger was not the content of films themselves, but rather the circumstances in which children went to cinemas - playing truant from school, or stealing and begging to pay for tickets -, and the contacts made therein, as urban gangs routinely used cinemas as recruiting grounds. ${ }^{86}$ In an attempt to recapture this liminal space and reach out to both delinquents and their parents, the director of the Gold Coast Film Unit, Sean Graham, was commissioned to create an educational film on delinquency. Graham directed the 1952 feature-length film The Bоy Kumasenu - a film so popular it "turned the whole of Accra upside down"- which explicitly discussed the social dangers posed by juvenile delinquency, and the role that upstanding African citizens could play in rescuing youths from the temptations of crime. ${ }^{87}$ Whilst youths, delinquent or otherwise, in urban environments such as Lagos, the Copperbelt and South Africa were influenced by American movies to mimic cowboy cultures or gangster styles, evidence suggests that in the Gold Coast children instead impersonated American soldiers, influenced by the stationing of foreign troops in the territory during the war. ${ }^{88}$ It was not until the 1950 s when gangster styles became more prevalent, with the senior probation officer noting the existence of "pimps and zoot boys" among the delinquents he oversaw. ${ }^{89}$ The Gold Coast's delinquents, and children in general, were seeking ways to engage with global modernities on their own terms and in their own interests. 
Fearing the Delinquent: Intelligence, Education and Delinquency

Whilst debates on delinquency in Lagos and other West African cities focused on the threat posed by juvenile gang violence and "hooligans", Gold Coast officials fixated instead on the danger posed by the "semi-educated" and intelligent African youth who seemingly chose a life of deviance rather than turning to crime through necessity. With an educated coastal intelligentsia leading political opposition to colonialism, concern about an uncontrollable and potentially criminal educated youth highlights fears about the weakness of colonial hegemony. As early as 1911, the Legislative Council had noted that "the class of youths to be dealt with in this country is different from the type to which English enactments apply in that they are drawn from a higher and better educated social stratum". ${ }^{90}$ Children of government employees, policemen, skilled workers, clerks and school teachers comprised nearly half of offenders brought before colonial courts, and were "more prone to becom[ing] recidivists". 91 Intelligence was equated in official narratives with an aptitude for deviant, criminal behaviour: "[h]e seems a bright and intelligent lad who may easily turn into an enterprising and dangerous criminal if he does not receive training and discipline". ${ }^{92}$ "Detribalized" urban orphans and "tarbooshi" [orphaned or abandoned children], known for their "grit...ingenuity... and unfailing good humour" were also regarded as potential delinquents whose shrewdness could draw them into criminality. ${ }^{93}$ From the perspective of both social science and popular opinion, the greatest problem was posed by youths who had received a few years of schooling before dropping out, whether willingly or under pressure of employment, migration or reduced family finances. ${ }^{94}$ After conducting a series of interviews with such delinquents, Tooth noted 
that "[i]mmaturity of character rather than low intelligence was the outstanding characteristic" of those boys, who displayed "a striking absence of any desire to work or secure more than a day-to-day existence". Although Tooth was unusually retrograde in his attitudes to race and rehabilitation within the context of the Department of Social Welfare, his views were reflective of wider colonial tropes about Africans' perceived inability to take responsibility for their own destiny. ${ }^{95}$

Overall, concerns about 'semi-educated' and intelligent delinquents were both driven and exacerbated by wider political and economic tensions in the Gold Coast. With the collapse of the wartime boom after 1947-8 leading to a decline in employment opportunities in both traditional occupations and urban economies, Busia found an ever-growing body of potential delinquents among school leavers: "Nothing could be worse for them than hanging around town earning a few shillings by undertaking odd commissions or collecting a 'dash' [payoff]... and learning the art of wasting time and living on other people". ${ }^{96}$ This provides support for strain theories of delinquency, in which delinquent behaviour is generated by youths' inability to achieve desire goals of employment, status and adulthood due to a lack of available opportunities. ${ }^{97}$ Other forms of employment in informal economies, like hawking, pilot boys, or portering for trade goods at transport hubs, overlapped spatially and socially with categories of delinquency and the policing of child labour. Official concerns about urban unemployment and detribalization merged with fears about African nationalism as generational discontent was mobilized by nationalist movements through the creation of youth wings, including the co-option of youth to the Convention People's Party and nationalist movements in Ashanti. ${ }^{98}$ J. C. Hamilton reflected upon the effects of this burgeoning nationalist movement on youth behaviour in a 1953 pamphlet for African readers, arguing against "the dangerous and 
thoughtless use of catch phrases which may lead the young and inexperienced in a

revolt against authority". ${ }^{99}$ The archival record however questions this link between nationalism and juvenile delinquency: even during the anti-colonial riots in Accra, February 1948, the charges upon which children were brought before Juvenile Courts were not linked to nationalist agitation, remaining criminal rather than political offences, and children - as distinct from youth more broadly - seem to have had limited direct involvement in the Ghanaian nationalist movement overall.

Punishing and Reforming the Delinquent: Disciplinary Techniques and Structures

In the late-colonial era the Colonial Office encouraged penal reform across the British Empire as marker of good governance. ${ }^{100}$ However, with limited resources, burgeoning prison populations and a continued belief that violence was necessary in the management of criminal subjects, reform proved largely illusory. Reformist efforts therefore became focused on one "manageable, malleable, sub-category of offenders: juvenile delinquents", as a way of reclaiming the future of colonial society. ${ }^{101}$ For Foucault, the delinquent is a construction of modern disciplinary regimes: "a person who offends because of their past life, uniquely requiring an institution like a prison to reconstruct their entire life in the form of specialist knowledge". ${ }^{102}$ Such specialist knowledge manifested itself in the Gold Coast through the peno-legal nexus of the probation officer, the juvenile court and the industrial school. However, the archival records suggests that reform - both of juvenile justice and individual offenders - proved incomplete and of limited effectiveness.

As part of post-war reforms, a system of juvenile courts was established to remove young offenders from the adult criminal justice system, beginning in Accra in 
1946. These courts were composed of a specially-appointed juvenile court magistrate, sitting with two members of a predominantly Ghanaian lay advisory panel and informed by probation officers' pre-trial investigations. The detection of delinquency increased exponentially as the juvenile court system expanded. From 227 cases heard in Accra, Kumasi and Sekondi in 1950, by 1952814 cases were heard, rising to 1200 in 1953 when new courts were opened in Cape Coast and Koforidua. ${ }^{103}$ The establishment and expansion of probation services after 1946 proved to be the critical surveillance and knowledge-gathering mechanism for the colonial state in regards to delinquency allowing it to expand its authority into the domestic sphere, transmitting metropolitan ideals of childhood and appropriate childrearing to families and courts. ${ }^{104}$ The question that African magistrates and probation officers were increasingly asking by the 1950s was whether it was a "faulty domestic atmosphere" or "wilful perversity" that created delinquents? ${ }^{105}$ Whilst colonial welfarist discourses, drawing on metropolitan theories and racialized constructions of urban Africa, still tended to place blame on failed parenting and environment in creating "young rascals", African probation officers themselves, working on an individual basis with children, were as likely to suggest that it was children's own agency or "bad friends rather than a poor home leading him into delinquency". ${ }^{106}$

From the 1930s officials had increasingly talked not of "punishing" delinquents, but of their "treatment". The main priority was to prevent children being sent into the morally-contaminating environment of prison. Before 1946 male youth offenders had been routinely dealt with by corporal punishment, following both metropolitan precedent and local disciplinary tradition. Whipping was long regarded as the most salutary, cost-effective and efficient sanction, being enacted in eighty per cent of cases between 1930 and 1938, decreasing slightly to seventy-four per cent 
during the war years. ${ }^{107}$ Some whippings were spectacles of violence: the District Magistrate of Kumasi noted the "objectionable" nature of one whipping (which he himself had ordered), recounting how the fifteen or sixteen year old boy was "stripped naked in the Police compound, held down, screaming and struggling, upon a bench by four policemen, and beaten by a fifth. The fourth stroke - as I personally observed drew blood". ${ }^{108}$ As sensibilities towards the infliction of bodily violence upon both criminals and children shifted in the metropole however, the Colonial Office exerted increasing pressure to limit the use of corporal punishment. ${ }^{109}$ Growing numbers of youthful recidivists led Gold Coast officials to believe that whipping had little impact on the more criminally-inclined youth, "as, as administered by law, it is less severe than [the boy] would get at home and little different from what he has been accustomed to expect in school". ${ }^{110}$ Instead, reformatories and probation became the main methods of treatment for juveniles, replacing bodily punishment with moral supervision and training. Officials were also encouraged to "enlis[t] the principles of tribal responsibility on behalf of law and order", and bolster generational authority in the face of a crisis in parenting. ${ }^{111}$ In an attempt to engage African communities in colonial schemes for social reform, a system of "Fit Persons", who included teachers, religious leaders and respected businessmen, was established after 1945 to provide an alternative to corporal punishment or institutional care by housing juvenile offenders in "exemplary" domestic environments. ${ }^{112}$ Corporal punishment was certainly avoided as a sanction by the Juvenile Courts, who showed a clear preference for ordering probation, supervision or recognisance. However, this was no simple unilinear evolution away from corporeal sanctions and the infliction of pain upon the subject body to 'modern' disciplinary technologies. ${ }^{113}$ With limited community engagement, institutional inertia and insufficient space for detention, corporal 
punishment remained a common sanction for juvenile and young offenders, with 189 sentences being handed down in 1953, compared to 185 mandates for detention in approved institutions and 130 probation orders. ${ }^{114}$ An average of 292 young offenders aged between sixteen and twenty were still incarcerated annually between 1947 and $1956 .{ }^{115}$

As outlined previously, the first institution specifically constructed to reform the Gold Coast's delinquent and criminal youth in 1929 was Ada Boys' School, a repurposed Native Authority Prison north of Tamale: very much a rural environment chosen to combat an urban problem. Following Nigerian precedent, control of Ada was initially handed over to the Salvation Army, less out of a belief in the necessity of spiritual uplift and more to avoid identification with the prison system and limit state outlays. ${ }^{116}$ The school provided care and basic training for up to fifteen boys under the age of eighteen. ${ }^{117}$ As concerns about delinquency increased, Ada became overstretched sparking a period of near-continuous, if somewhat haphazard, institutional expansion. The Boy's School moved (and changed name) three times between 1936 and 1947, from Ada to Kintampo, to Mampong, to the renamed Industrial School at Agona Swedru which had a capacity for 128 boys. Responsibility for supervising the juvenile institutions was also shifted from the Salvation Army, via Education, to the newly formed Department of Social Welfare in 1945. That year, the first Industrial Institution was established in Sekondi to cater for boys between sixteen and twenty-one years of age who required "real corrective training", under control of the Prisons Department. ${ }^{118}$ However, this only tackled the tip of the iceberg: 936 young offenders were still incarcerated in adult prisons in 1946-7 alone. The last years of colonial rule continued the rapid expansion of institutional measures to combat delinquency: by 1954 a second Boys Industrial School was built at Tamale, an 
Industrial School for Girls in Accra, and various Remand and Probation Homes were established around the colony. ${ }^{119}$ This nexus of institutional structures was intended as a showcase for the benefits of British welfarism and reform, demonstrating the practicability of creating 'productive subjects' for official audiences, but also to show the power of colonial discipline and modernity to African audiences. Some younger boys clearly welcomed the safety and security that could be found in reformatory institutions, seeing them as to be preferable to their other life options: "I have plenty of food and get no trouble...I would like to stay in the Home for two more years and do not want to return to my town. My father is dead. The Boy's Home do not annoy me". ${ }^{120}$

Within this reformative project there was a persistent dichotomy however between physical discipline, labour, and education in reclaiming the delinquent from deviance: in essence, between efforts of colonial governance to reform through the body and the mind. Konate and Thioub have argued that in colonial Senegal, moral reformation in penitentiary schools was based on a process of coercing the body, primarily through physical labour. ${ }^{121}$ In the Gold Coast, this function of physical coercion geared towards the creation of economically productive citizens was wrapped within a veneer of moral development and delivered through the imposition of English educational tradition. At Agona Swedru, the Industrial School was very much modelled along the lines of an English public school, with four houses and a prefect's council, and the eventual establishment of a Boy Scouts troop. ${ }^{122}$ The daily routine was strictly regimented in a disciplinary fashion from the 5.55am rise to prayers and bed at $8.15 \mathrm{pm}$, with physical training and sports sessions daily, and a marks system rewarding good behaviour with the aim of encouraging "essential qualities of self-unfoldment [sic] of the individual boy". ${ }^{123}$ There was however a 
continual tension between 'education' and 'economic production' within this regime, mirroring patterns of adult prison labour. ${ }^{124}$ At Kintampo Industrial School formal schooling was provided for only ninety minutes each day, with reportedly poor standards of teaching. The main focus was on vocational training, with tailoring, carpentry and agriculture supposedly taught, although in practice, there were only teachers for agriculture. ${ }^{125}$ Agricultural training became favoured as a supposedly culturally-appropriate method to combat perceived urban "detribalization" and encourage delinquents to move to rural environments after release; most boys however rejected this bucolic ideal and returned straight back to the towns. ${ }^{126}$ As the reformatory system expanded, the boys' labour was used to construct additional buildings: this was described as training, but primarily served to reduce costs. ${ }^{127}$ The Borstal School in Maamobi, Accra focused its efforts on training boys to master two trades before discharge, explicitly aiming to provide semi-skilled labour to boost the local economy. ${ }^{128}$ Aftercare for juvenile offenders moreover focused primarily on locating employment, with waged labour providing the strongest pathway towards a stable, 'respectable', life and passage into adulthood.

It is questionable how successful juvenile reform was in its objective to create law-abiding, productive subjects however, and official documentation in the colonial archive tends to overemphasize the amount of rehabilitation occurring. The Kintampo Industrial School was a failure, discharging boys "untrained certainly and probably depraved, with aid and guidance into an unfriendly world". ${ }^{129}$ By the 1950 s growing numbers of youths placed in the system made it increasingly difficult to separate the ideals of protection and rehabilitation from the reality of confinement and criminalization. ${ }^{130}$ Older boys in particular directly challenged the authority of school personnel, providing a disruptive example through their disobedience, aggression and 
absconding, with staff resorting to caning recalcitrant boys or transferring them to prison. ${ }^{131}$ Welfare officials insisted that the Industrial School had a low re-offending rate of ten to seventeen per cent, but it is unclear if those figures include former inmates who aged into 'adult' offender categories. ${ }^{132}$ Even those former delinquents who did become law-abiding, productive citizens; were they reformed by the system or did they simply mature out of deviant behaviours and become re-socialized into "respectable" adults within their own communities? Many officials certainly agreed with Tooth when he argued that English Borstal model was "psychologically unsuited to Africans and has little moral backing and no deterrent value". ${ }^{133}$ But what is striking about the case records for juvenile delinquents is how many parents actively called for their children to be sent to government institutions, usually after initial attempts to correct delinquent behaviour through physical chastisement or removing the child to another family member's household had failed. ${ }^{134}$ Kwaku Normah, a painter from Kumasi, told police that his son "is a bad boy, he used to steal from the house. I used to punish him in the house but he never takes my advice. [He] had been brought to the court and sentenced to strokes for things he stole from outside. I cannot control [him] so I wish that he may be sent away to the Boys Industrial School". ${ }^{135}$ Only families of a higher social standing appeared anxious that their children "should avoid the stigma of being sent to an Industrial Home and asked [they] might be whipped instead". ${ }^{136}$ Juvenile delinquency challenged generational as well as racial structures of social, economic and legal power, encouraging parental and political authorities to strike bargains of control over the future of Gold Coast childhood.

\section{Conclusions}


In the Gold Coast, as elsewhere in colonial Africa, juvenile delinquency became a focus for concern in the mid-twentieth century, drawing on contemporary fears about the impact of urbanization, industrialization and European cultures creating “detribalized" Africans. After the Second World War, such concerns about controlling urban populations were exacerbated by the rise of anti-colonial and nationalist agitation. With the post-1945 reconfiguration of colonial governance along welfarist and interventionist lines, youth became a growing target for colonial control, and juvenile delinquency offered an increasingly potent challenge to that control. For colonial states, juvenile delinquency became a symbol of the failure of colonial authority and modernity, of their loss of control over the future. However, although numbers of delinquents increased sharply in the late colonial era, they remained small enough to be a manageable target for identification, explanation and treatment. Juvenile delinquency as a legal, social and historical category in the Gold Coast emerged out of the intersection between such colonial disciplinary projects, and from the socio-economic, cultural and generational tensions within urban African communities. Colonial theories of delinquency, focusing on environment and parental responsibility, largely occlude children's agency in their own actions. With the increasing Africanization of welfare and probation services, and the development of new disciplinary apparatus, a greater light was shone on children's agency. Some children engaged in behaviour deemed delinquent simply to survive, sleeping rough and stealing food where possible. But whilst "the bulk of juvenile crime [was] more mischievous acquisitiveness dictated by opportunity than premeditated lawlessness", other offenders showed clear, determined motivations for their actions, shaped by a desire to engage with modern urban and material cultures, and in many cases were socialized into delinquent activities through youth gangs or acquaintances. ${ }^{137}$ In these 
cases the line between 'delinquency' and nascent criminality was blurred. What the study of delinquency reveals is that children were actively, and calculatedly, engaging with modern, global goods and cultures within these urban environments as a means to accumulate status and wealth on the path towards adulthood.

The treatment of juvenile delinquency was constructed to satisfy to contrasting sets of penal and administrative criteria (however imperfectly), operating at both local and imperial levels. On one hand, youths had to be punished for their offences to deter future offenders and maintain the boundaries of colonial social control. On the other, juveniles had to be 'reformed', according to metropolitan policy and discourse, showing that Africans could be reclaimed from disorder and disobedience, symbolically establishing the power of colonial modernity and development, and its role in securing Africa' future. Official concerns in the Gold Coast about "intelligent" and "educated" delinquents and their potential slide into criminality highlight how fears about wider nationalist agitation were reflected in the treatment of juvenile delinquency, whilst the relative failure of reformist treatment and the ever-increasing numbers of delinquents passing through Juvenile Courts showed colonial officials the limits of their own coercive and disciplinary capabilities. Expanding constructions of delinquency certainly created a 'crime wave' in the courts, but did not address the causes of disorder: nor did reformatories easily transform all young offenders into citizens. ${ }^{138}$ As the personal records of delinquents suggest, individual agency could be as significant as social and economic structures at shaping patterns of childhood behaviour. Whilst it is hoped that this article has provided a useful analysis of colonial constructions of delinquency in the Gold Coast, further archival and oral research is required to elucidate local understandings of delinquency, criminality and youth 
cultures, and to explore the tensions between delinquent youths and adult populations

in urban communities across the colony.

Many thanks are due to Simon Heap and Jack Lord for their helpful comments and information shared, and to the reviewers for their insightful suggestions.

${ }^{1}$ Letter from Ama Badua, K.E., CSO 4/5/41, Public Records and Archives Administration Department, Accra [PRAAD].

${ }^{2}$ Ioné Acquah, Accra Survey: A Social Survey of the Capital of Ghana formerly called the Gold Coast, undertaken for the West African Institute of Social and Economic Research 1953-6 (London:

University of London Press, 1958), 28. On juvenile delinquency in colonial Africa see Richard Waller, "Rebellious Youth in Colonial Africa," Journal of African History, 47, no. 1 (2006): 77-92; Laurent Fourchard, "Lagos and the Invention of Juvenile Delinquency in Nigeria, 1920-60," Journal of African History, 47, no. 1 (2006): 115-37 and "The Making of the Juvenile Delinquent in Nigeria and South Africa," History Compass, 8, no. 2 (2010): 129-42; Simon Heap, “'Jaguda boys': Pickpocketing in Ibadan, 1930-60," Urban History, 24, no. 3 (1997): 324-43 and "“Their Days are Spent in Gambling and Loafing, Pimping for Prostitutes, and Picking Pockets': Male Juvenile Delinquency on Lagos Island, 1920-60s," Journal of Family History, 35, no. 1 (2010): 48-70; Chloe Campbell, "Juvenile Delinquency in Colonial Kenya, 1900-39," The Historical Journal, 45, no. 1 (2002): 129-51; Andrew Burton, "Urchins, Loafers and the Cult of the Cowboy: Urbanization and Delinquency in Dar-esSalaam, 1919-61,” Journal of African History, 42, no. 2 (2001): 199-216; Paul Ocobock, “Joy Rides for Juveniles: Vagrant Youth and Colonial Control in Nairobi, Kenya, 1900-52," Social History, 31, no.1 (2006): 39-58.

${ }^{3}$ Waller, "Rebellious Youth," 79.

${ }^{4}$ See Heather Ellis, "Introduction: Constructing Juvenile Delinquency in a Global Context", in Juvenile Delinquency and the Limits of Western Influence, 1850-2000, ed. Heather Ellis (London: Palgrave Macmillan, 2014), 1-16.

5 Satadru Sen, “A Separate Punishment: Juvenile Offenders in Colonial India,” Journal of Asian Studies, 63, no. 1 (2004): 81-104.

${ }^{6}$ See Linda Chisholm, "The Pedagogy of Porter: The Origins of the Reformatory in the Cape Colony, 1882-1910," Journal of African History, 27, no. 3 (1986): 481-95; Ibrahima Thioub, “"Marginalité juvenile et enfermement à l'époque coloniale: les premières écoles pénetentiares du Sénégal, 18881927,", in Enfermement, prison et châtiments en Afrique: du 19e siècle à nos jours, ed. Florence Bernault (Paris: Karthala, 1999), 70-96.

${ }^{7}$ See Peter King, "The Rise of Juvenile Delinquency in England, 1780-1940: Changing Patterns of Perception and Persecution,” Past \& Present, 160, no. 1 (1998): 116-66.

${ }^{8}$ Report of the Juvenile Delinquency Sub-Committee appointed in Feb 1, 1942, Juvenile Delinquency 1941-2, CO 859/73/11, British National Archives, London [TNA].

${ }^{9}$ Sen, "A Separate Punishment," 84.

${ }^{10}$ John Iliffe, The African Poor: A History (Cambridge: Cambridge University Press, 1987), 187.

${ }^{11}$ Acquah, Accra Survey, 28-9.

${ }^{12}$ Report by Mr A. Paterson, Social Welfare Work in the Colonies West Africa - Gold Coast, CO 859/123/1, TNA. See Joanna Lewis, Empire State Building: War and Welfare in Kenya, 1925-52 (Oxford: James Currey, 2000), 70-8.

${ }^{13}$ These papers are a matter of public record, but names of juvenile offenders have been redacted and replaced with initials protect their privacy.

${ }^{14}$ See Taylor Sherman, "The Tensions of Colonial Punishment: Perspectives on Recent Developments in the Study of Coercive Networks in Asia, Africa and the Caribbean," History Compass, 7, no. 3 (2009): 659-77.

${ }^{15}$ Catherine Koonar, "CChristianity, Commerce and Civilization': Child Labor and the Basel Mission in Colonial Ghana, 1855-1914”, International Labor and Working Class History, 86, no. 3, (2013): 72.

See Philippe Ariès, L'enfant et la vie familiale sous l'ancien regime (Paris: Plon, 1960); Allison James, Chris Jenks and Alan Prout, Theorizing Childhood (Cambridge: Polity Press, 2008).

${ }^{16}$ See Paula S. Fass, "Children and Globalization", Journal of Social History, 36, no. 4 (2003): 963-77; Audra A. Diptee and Martin A. Klein, "African Childhoods and the Colonial Project," Journal of Family History, 35, no. 1 (2010): 1-6; Saheed Aderinto ed., Children and Childhood in Colonial Nigerian Histories (London: Palgrave Macmillan, 2015). 
${ }^{17}$ Sharon Stephens, "Children and the Politics of Culture in Late Capitalism", in Children and the Politics of Culture, ed. Sharon Stephens (Princeton: Princeton University Press, 1996), 3-48.

${ }^{18}$ Jacqueline Bhabha, "The Child - What Sort of Human?", PMLA, 121 (2006): 1526-35; Erica

Burman, "Innocents Abroad: Western Fantasies of Childhood and the Iconography of Emergencies", Disasters, 8, no. 3 (1994): 238-52.

${ }^{19}$ Afua Twum-Danso, "The Political Child" in Invisible Stakeholders: Children and War in Africa, ed., Angela McIntyre (Cape Town: Institute for Security Studies, 2005), 12-3.

${ }^{20}$ Jack Lord, "The History of Childhood in Colonial Ghana, c. 1900-57," PhD thesis, SOAS, 2012

${ }^{21}$ Alcinda Honwana and Filip de Boeck eds., Makers \& Breakers: Children and Youth in Postcolonial Africa (Oxford: James Currey, 2005); Jean Marie Allman, "The Youngmen and the Porcupine: Class, Nationalism and Asante's Struggle for Self-Determination, 1954-7," Journal of African History, 31, no. 2 (1990): 263-79.

${ }^{22}$ See Meyer Fortes, Social and Psychological Aspects of Education in Taleland (Oxford: Oxford University Press, 1938); R. S. Rattray, Akan-Ashanti Folktales (Oxford: Clarendon Press, 1930); Gold Coast Leader, 30 July 1904.

${ }^{23}$ Gold Coast Legislative Council Debates, 1911, CO 98/19, TNA.

${ }^{24}$ Governors' Annual Address to the Executive Council, 1927-9, CO 98/52, TNA.

${ }^{25}$ Glover-Addo to Colonial Secretary Maxwell, Gold Coast Legislative Council Debates 1924-5, CO 98/45, TNA.

${ }^{26}$ Dispatch no. 611 Acting Governor Thomas to Secretary of State for the Colonies, Gold Coast Legislative Council Debates, 1929-30, CO 98/54, TNA; Gold Coast Legislative Council Debates 19245, CO 98/45, TNA; Simon Heap, "Processing Juvenile Delinquents at the Salvation Army Boys' Industrial Home in Lagos", in Children and Childhood in Colonial Nigerian Histories, ed. Saheed Aderinto (London: Palgrave Macmillan, 2015), 49-76.

${ }^{27}$ Colonial boundaries of childhood were themselves variable: fourteen was the minimum age for waged labour and marriage for males.

${ }^{28}$ Gold Coast Colony, Criminal Procedure Ordinance No. 5 of 1876, s.52, 81.

${ }^{29}$ Gold Coast Colony, Children (Care and Reformation) Act No. 22 of 1928, s. 22.

${ }^{30}$ Law Relating to Juvenile Offenders and Children- Changes in, CSO 4/10/110, PRAAD. Exact numbers are difficult to establish due to inconsistences in official figures, slippages between juvenile and young offender categories, and lack of recording for juveniles who came before courts other than specific Juvenile Courts.

${ }^{31}$ Juvenile Delinquents - Clinical Examination Prior to Admission, CSO 4/5/60, PRAAD.

${ }^{32}$ Y. A., 1936, CSO 15/11/41, PRAAD.

${ }^{33}$ Geoffrey Tooth, "A Survey of Juvenile Delinquency in the Gold Coast", unpublished report, Accra, $1946,1$.

${ }^{34}$ Ibid.

${ }^{35}$ See Kenya Colony, Report of the Committee on Juvenile Crime and Kabete Reformatory (Nairobi, 1934), AP/1/699, KNA; Juvenile Delinquency: Comments on Report by South African High Commission Territories, CO 859/74/1, TNA; Uganda Protectorate, Report of the McKisack Committee of Enquiry into the Problem of Juvenile Delinquency in Uganda (Entebbe: Government Printer, 1958); Juvenile Offenders: Bechuanaland, Basutoland, Swaziland, 1954-6, CO 859/580, TNA.

${ }^{36}$ See Cicely M. Craven, "Juvenile Delinquency in the Colonies," The Howard Journal of Criminal Justice, 4, no. 2 (1935): 179.

${ }^{37}$ P. N. Dalton, March 11, 1940, K. A., CSO 4/5/18, PRAAD.

${ }^{38}$ See Donald Shoemaker, Theories of Delinquency: An Examination of Explanations of Delinquent Behaviour (Oxford: Oxford University Press, $6^{\text {th }}$ ed., 2010), 101-19.

${ }^{39}$ K. A. Busia, Report on a Social Survey of Sekondi-Takoradi (London: Crown Agents for the Colonies, 1950), 85-6.

${ }^{40}$ Tooth, "Survey of Juvenile Delinquency", 13. Children interviewed for such studies were however usually drawn from those undergoing custodial sentences, and as children from broken homes were more likely to be recommended for such sentences, this skewed official data.

${ }^{41}$ Department of Social Welfare and Community Development, Welfare and Mass Education on the Gold Coast 1946-51 (Accra: Government Printer, 1953).

42 "Our Children and their Care", Gold Coast Times, February 4, 1939.

${ }^{43}$ Gold Coast Colony, Report on the Gold Coast for the Year 1947 (Accra: Government Printer, 1948) [hereafter Gold Coast, Annual Report].

${ }^{44}$ Department of Social Welfare and Community Development, "Problem Children of the Gold Coast", unpublished paper, c. $1954,8$. 
${ }^{45}$ The Daily Echo, January 19, 1955. See Jean Marie Allman and Victoria B. Tashjian, "I Will Not Eat Stone": A Women's History of Colonial Asante (London: Heinemann, 2000).

${ }^{46}$ C. B. C., CSO 4/5/63, PRAAD.

${ }^{47}$ S. Kirson Weinberg, "Juvenile Delinquency in Ghana: A Comparative Analysis of Delinquents and Non-Delinquents," Journal of Criminal Law, Criminology and Police Studies, 55, no. 4 (1964): 471; Catie Coe, "How Debt Became Care: Child Pawning and its Transformations in Akuapem, the Gold Coast, 1874-1929," Africa, 82, no. 2 (2012): 287-311; Diana G. Azu, The Ga Family and Social Change (Leiden: Afrika-Studiecentrum, 1974), 20; Barrington Kaye, Bringing Up Children in Ghana: An Impressionistic Survey (London: Allen and Unwin, 1962). On child migration, see Elodie Razy and Marie Rodet, eds., Children on the Move in Africa: Past and Present Experiences of Migration (London: James Currey, 2016).

${ }^{48}$ Weinberg, "Juvenile Delinquency in Ghana", 472.

${ }^{49}$ J. Rigby-Williams, "The Treatment of Juvenile Delinquency in the Gold Coast of West Africa," International Review of Criminal Policy, 6 (1954): 1. See N. E. Lawler, Soldiers, Airmen, Spies and Whisperers: The Gold Coast in World War II (Athens: Ohio University Press, 2002).

${ }^{50}$ Emmanuel Akyeampong, "Sexuality and Prostitution among the Akan of the Gold Coast, 16501950," Past \& Present, 156, no. 1 (1997): 144-73.

${ }^{51}$ K. D., 1943, CSO 4/5/41, PRAAD; Department of Social Welfare, Problem Children of the Gold Coast, 6. Epprecht suggests that coded language regarding boys and young men around ports, dancehalls and bars was actually a reference to male prostitution. As such 'pilot boys' might not only have facilitated female prostitution, but may have been thought themselves to engage in same-sex acts. Marc Epprecht, Heterosexual Africa? The History of an Idea from the Age of Exploration to the Age of AIDS (Athens, OH: Ohio University Press, 2008), p. 49.

${ }_{52}$ Busia, Survey of Sekondi-Tokoradi, 21-30.

${ }^{53}$ K. D., 1943, CSO 4/5/41, PRAAD.

${ }^{54}$ See Tooth, "Survey of Juvenile Delinquency", 6.

${ }^{55}$ Salvation Army Territorial Commander Ernest Bigwood to Director of Education, 7 September 1942, Boy's Industrial Home at Kintampo, CSO 15/11/80, PRAAD.

${ }^{56}$ Heap, “Jaguda boys'," 335.

${ }^{57}$ E. K., 1943-5, CSO 4/5/40, PRAAD.

${ }^{58}$ W. A. A. K., 1931, CSO 15/11/14, PRAAD.

${ }^{59}$ Tooth, "Survey of Juvenile Delinquency," 7; K. A., CSO 4/5/29; K. M., 1940, CSO 4/5/24, PRAAD. ${ }^{60}$ G. R., 1943-4, CSO 4/5/39, PRAAD.

${ }^{61}$ J. C. Hamilton, "Crime and Punishment," West African Affairs No. 29 (Accra: Staples Publication, 1953), 7.

62 Jack Lord, "Child Labour in the Gold Coast: The Economics of Work, Education and the Family in Late-Colonial Africa, c. 1940-57," The Journal of the History of Childhood and Youth, 4, 1 (2011): 88115.

${ }^{63}$ Ibid., 90.

${ }^{64}$ Shoemaker, Theories of Delinquency, 20.

${ }^{65}$ Acquah, Accra Survey, 54; S. Kirson Weinberg, "Urbanization and Male Delinquency in Ghana," Journal of Research in Crime and Delinquency, 2, no. 2 (1965): 85-94.

${ }^{66}$ Busia, Social Survey of Sekondi-Tokoradi, 21-30.

${ }^{67}$ O. K alias K. B., 1946, CSO 4/5/65, PRAAD.

${ }^{68}$ Heap, "Jaguda Boys”; K. B., 1945, CSO 4/5/61; O. M., Juvenile Record Book, 1954-6, SCT 17/5/301, PRAAD.

${ }^{69}$ K. N., 1940, CSO 4/5/25; K. K., 1941, CSO 4/5/33, PRAAD.

${ }^{70} \mathrm{An}$ increased focus on preventative reforms and concern about age-appropriate 'play' in the late 1950s saw 'boys clubs' established in urban environments by social workers to provide space and occupation for young males, but such non-custodial initiatives were largely unsuccessful in attracting potential deviant youths. Acquah, Accra Survey, 140.

${ }^{71}$ Weinberg, "Juvenile Delinquency in Ghana," 471.

${ }^{72}$ See T. M., 1939-40, CSO 4/5/28, PRAAD.

${ }^{73}$ See Dior Konate, "On Colonial Laws and the Treatment of Young Female Delinquents in Senegal: The Case of Léonie Guèye," Stichproben, 12 (2007): 37; Linda Chisholm, "Gender and Deviance in South African Industrial Schools and Reformatories for Girls, 1911-34," in Women and Gender in Southern Africa to 1945, ed. Cheryll Walker (London: James Currey, 1990), 293-312. 
${ }^{74}$ Tooth, "Survey of Juvenile Delinquency"; Abosede George, Making Modern Girls: A History of Girlhood, Labour and Social Development in Twentieth Century Colonial Lagos (Athens, OH: Ohio University Press, 2014).

75 "Children's Column by Uncle Charlie," Gold Coast Times, January 7, 1939.

${ }^{76}$ Fourchard, "Lagos and the Invention of Juvenile Delinquency," 125-6; Benedict B. B. Naanen, "Itinerant Gold Mines: Prostitution in the Cross River Basin of Nigeria, 1930-50," African Studies Review, 34, no. 2 (1991): 59; Saheed Aderinto, “"The Girls in Moral Danger': Child Prostitution and Sexuality in Colonial Lagos, Nigeria, 1930 to 1950," Journal of Humanities and Social Sciences, 1, no. 2 (2007): 1-12.

77 Weinberg, "Juvenile Delinquency in Ghana", 471. The ratio of boys: girls in Juvenile Courts remained 15:1. Rigby-Williams, "Treatment of Juvenile Delinquency," 12-3.

${ }^{78}$ Department of Social Welfare, "Problem Children," 6.

${ }^{79}$ Ibid.

${ }^{80}$ Gold Coast Colony, Report on the Treatment of Offenders for the Year 1951-2 (Accra: Government Printer, 1952); Hostels for Women and Girls, CSO 28/9/2, PRAAD.

${ }^{81}$ C. B., August 7, 1952, Juvenile Record Book Accra, 1952-4, SCT 17/5/300, PRAAD.

82 A. A., December 23, 1954, Juvenile Record Book Accra, 1954-6, SCT 17/5/301, PRAAD.

${ }^{83}$ Burton, "Urchins, Loafers," 200; Gold Coast, "Children and the Cinema: A Report on an Enquiry into Cinema Going among Juveniles undertaken by the Department of Social Welfare and Community Development in Accra and Kumasi, 1954", unpublished report, 2-4, 6, 10.

${ }^{84}$ Department of Social Welfare, Problem Children, 4; The Daily Echo, January 19, 1955.

${ }^{85}$ O. F., August 1952, Juvenile Court Record Book Accra 1952-4, SCT 17/5/300, PRAAD.

${ }^{86}$ Gold Coast, "Children and the Cinema," 3.

${ }^{87}$ See Peter J. Bloom and Kate Skinner, "Modernity and Danger: The Boy Kumasenu and the Work of the Gold Coast Film Unit," Ghana Studies, 12/13 (2009/10): 121-153.

${ }^{88}$ Heap, "“Their Days are Spent in Gambling"; Charles Ambler, "Popular Films and Colonial Audiences: The Movies in Northern Rhodesia," American Historical Review, 106, no. 1 (2001): 81105; Chloe Campbell, "Learning to Kill? Masculinity, the Family and Violence in Natal," Journal of Southern African Studies, 18, 3 (1992): 614-28; Burton, "Urchins, Loafers," 199-216; Busia, Social Survey, 95.

${ }^{89}$ Rigby-Williams, "Treatment of Juvenile Delinquency," 1; Tooth, "Survey of Juvenile Delinquency".

${ }^{90}$ Gold Coast Legislative Council Debates, 1911, CO 98/19, TNA.

${ }^{91}$ O. S., K. A., K. E., 1940, CSO 4/5/22; K. A., 1944, CSO 4/5/54, PRAAD.

${ }^{92}$ K. J., 1937, CSO 15/11/43, PRAAD.

${ }^{93}$ Acting Chief Inspector of Labour, 14 March 1942, Juvenile Delinquency and Welfare - Policy, CSO 15/3/340, PRAAD.

${ }_{94}$ Acquah, Accra Survey, 74-5; Busia, Social Survey of Sekondi-Takoradi, 84; Department of Social Welfare, "Problem Children," 6; Lord, "Child Labour," 92-8. Attending school could also be a pathway to delinquency, with missionaries and school teachers reporting that many "young thieves had begun to steal as starving school children" when not given money for food by their parents. Report by Mr A. Paterson, CO 859/123/1, TNA; Daily Echo, January 19, 1955. On education, see Lacy S. Ferrell, "Fighting for the Future: A History of Education in Colonial Ghana, c. 1900-1940," PhD thesis, University of Wisconsin-Madison, 2013.

${ }^{95}$ Tooth, "Survey of Juvenile Delinquency," 19; Jock McCulloch, Colonial Psychiatry and the African Mind (Cambridge: Cambridge University Press, 1995).

${ }^{96}$ Busia, Social Survey of Sekondi-Takoradi, 37, 22.

${ }^{97}$ Shoemaker, Theories of Delinquency, 120.

${ }^{98}$ Allman, "The Youngmen and the Porcupin". There are interesting discursive parallels between colonial descriptions of these youths and postcolonial concerns about 'rarray-boys' and 'youth revolutions' in the 1980-90s. See Donald B. Cruise O'Brien, "A Lost Generation? Youth Identity and State Decay in West Africa," in Postcolonial Identities in Africa, eds., Richard Werbner and Terence Ranger (London: Zed Books, 1996), 55-74.

${ }^{99}$ Hamilton, "Crime and Punishment," 7.

${ }^{100}$ See Advisory Committee on the Treatment of Offenders records, CO 829 series, TNA.

${ }^{101}$ Stacey Hynd, "Insufficiently Cruel' or 'Simply Inefficient'? Discipline, Punishment and Reform in the Gold Coast Prison System, Ghana c. 1850-1957', in Transnational Penal Cultures: New Perspectives on Discipline, Punishment and Desistance, eds. Vivien Miller and James Campbell (London: Routledge, 2015), 33. 
${ }^{102}$ Michel Foucault, Surveiller et Punir: Naissance de la Prison (Paris: Éditions Gallimard, 1975), 2525 .

${ }^{103}$ Gold Coast, Annual Report 1953. These numbers include cases heard in Juvenile and ordinary courts.

${ }^{104}$ Lord, "History of Childhood", 93.

${ }^{105}$ E. A. L., July 24, 1952, Juvenile Court Record Book Accra, SCT 17/5/300, PRAAD.

${ }^{106}$ A. T., September 2, 1946, Juvenile Court Record Book Accra, SCT, 17/5/299, PRAAD.

${ }^{107}$ Gold Coast Colony, Annual Police and Prisons Reports 1930-38; Tooth, "Survey of Juvenile Delinquency," 6. Females were exempt from corporal punishment. Although described as "whipping, the practice is more likely to have been caning with a rod rather than a whip. Corporal Punishment for Juvenile Offenders - Authority of Native Tribunals to order infliction of, CSO 4/1/1/183, PRAAD.

${ }^{108}$ District Magistrate Kumasi to Chief Registrar, January 16, 1942, Juvenile Delinquency and Welfare, CSO 15/3/429, PRAAD. The boy reoffended shortly afterwards.

${ }^{109}$ Home Office, Report of the Departmental Committee on Corporal Punishment (London: HMSO, 1938), Cmd. 5684; Report of the Juvenile Delinquency Sub-Committee February 1942, CO 859/73/11, TNA. See Steven Pierce, "Punishment and the Political Body: Flogging and Colonialism in Northern Nigeria," in Discipline and the Other Body: Correction, Corporeality, Colonialism, eds. Steven Pierce and Anupama Rao (Durham: Duke University Press, 2006), 186-214; Murray Last, "Children and the Experience of Violence: Contrasting Cultures of Punishment in Northern Nigeria," Africa, 70, no. 3, (2000): 359-93.

${ }^{110}$ Report by Geoffrey Tooth, Colonial Social Science Research Council, Minutes and Papers 1-40, 1947, CO 901/4, TNA; Department of Social Welfare and Housing, Report of the Principal Probation Officer (Accra: Government Printer, 1947).

${ }^{111}$ Craven, "Juvenile Delinquency in the Colonies," 179.

${ }^{112}$ Destitute Children under the Guardianship of Certain Individuals, CSO 28/6/1, PRAAD.

${ }^{113}$ Foucault, Surveiller et Punir.

${ }^{114}$ Gold Coast, Annual Report 1953. Offenders from Northern Territories were notably overrepresented in custodial sentences as they could not easily be put in care of relatives.

${ }^{115}$ Gold Coast, Annual Reports 1949-57 and Prisons Annual Reports, 1949-57.

${ }^{116}$ See Fourchard, "The Invention of Juvenile Delinquency".

${ }^{117}$ Gold Coast Colony, Report on the Prisons Department for the Year, 1930-1 (Accra: Government Printer, 1931) [hereafter Prisons Annual Report]. Committals were usually eighteen months to three years in duration. Boy's Industrial Home Kintampo - Reports on, CSO 15/11/80, PRAAD.

${ }_{118}$ Gold Coast, Annual Reports 1947, 1951. In 1950 the Industrial Institution, which had moved to Maamobi, was renamed as the Borstal School to avoid confusion with the Industrial School.

${ }^{119}$ Gold Coast, Prisons Annual Report, 1953-4.

${ }^{120}$ S. F., 1929, CSO 15/11/11, PRAAD.

${ }^{121}$ Konate, "The Case of Léonie Guèye," 47; Thioub, "Marginalité juvenile".

${ }^{122}$ Gold Coast, Annual Report 1947.

${ }^{123}$ Boy's Industrial Home Kintampo- Reports on, CSO 15/11/80, PRAAD.

${ }^{124}$ Stacey Hynd, ““...A Weapon of Immense Value': Convict Labour in British Colonial Africa, c.1850-1950s' in Global Convict Labour, eds. Alex Lichtenstein and Christian de Vito (Leiden: Brill, 2015), 419-459.

${ }^{125}$ Report by Provincial Inspector of Education J. A. Addo, February 15, 1942, Juvenile Delinquency and Welfare - Policy and General Consideration, CSO 15/3/340, PRAAD.

${ }^{126}$ Agricultural training was also supposed to teach the boys the benefits of hard physical labour and give them a productive vocation whilst simultaneously exhausting them to ease the maintenance of discipline and reduce expenditure on consumables for the school. Boys' Industrial Home at Kintampo, CSO 15/11/80, PRAAD.

${ }^{127}$ Gold Coast, Annual Report 1949, 1954.

${ }^{128}$ Prisons Annual Report, 1937-8.

${ }^{129}$ Report of Alexander Paterson on the Treatment of Crime in the Gold Coast, c. 1944, cited in Lord, "Histories of Childhood", 109.

${ }^{130}$ Waller, "Rebellious Youth," 79.

${ }^{131}$ K. L., 1941, CSO 4/5/21; T. M., 1939-40, CSO 4/5/28; K. B. A., 1943, CSO 4/5/45, PRAAD.

Punishments ranged from cessation of pocket money, strict drill and task work, to caning. Prisons Annual Report, 1947-8.

${ }^{132}$ Gold Coast, Annual Report 1950, 1951, 1952.

${ }^{133}$ Report by Tooth, CO 901/4, TNA. 
${ }^{134}$ K. D., 1940, CSO 4/5/20; K. M. 1941-6, CSO 4/5/30; PRAAD.

${ }^{135}$ K. A., 1936, CSO 15/11/38, PRAAD.

${ }^{136}$ Y. P., 1935, CSO 15/11/34, PRAAD.

${ }^{137}$ Report by Geoffrey Tooth, 147, Colonial Social Science Research Council, Minutes and Papers 140, 1947, CO 901/4, TNA.

${ }^{138}$ Waller, "Rebellious Youth," 85. 